\title{
Contemporary Development and Sustainability Indicators at the Royal Commission of Yanbu
}

\author{
Ayedh A.AlShehai ${ }^{1}$
}

\begin{abstract}
Contemporary development in the Royal Commission of Yanbu (RCY) relies on the comprehensive set of sustainability indicators which have been developed through forty years of experience and studies. The city was built in 1974, with the concept of sustainable development for the oil and petroleum industries which serves the community with a population of 115,000 . Recently, the RC won many international awards in development under the United Nation Development Program (UNDP) which is considered an indicator for positive progress in sustainability. The aim of this paper is to explore twelve sustainability indicators implemented at RCY. The proposed sustainability indicators were contributed by nine divisions. The methodology in selecting indicators in terms of measurable success was crafted through the knowledge of local and international organizations such as UNDP, European Union (EU), and Environment Protection Agency (EPA). The findings show that RCY has predominantly made excellent progress in sustainability by accomplishing the goal of efficiency in resources and materials. There are twelve categories designed for sustainable development at the RCY. It contains a comprehensive set of indicators updated annually. In conclusion: sustainability indicators influence the growth of income and made harmonious between the economies and the community at RCY.
\end{abstract}

Keywords: sustainability indicators, quality of life, sustainability development, harmony, industrial, economy and communities, environment.

\section{Introduction}

Sustainability is the spirit of the modern approach for alerting people of a problem before it's happened, and direct policy makers to which way to go for the best solution Charles, et al, [1]. From the literature review, as the definitions of sustainability are various, this is defined according to the frame of reference. However, in this paper the author focused on sustainability for a city which is designed for the petroleum industry. It required common developing pillars at any society; these are economy, community, as well as resources. More factors are developed with the relapse of time and added to the three pillars which shaped the current practice of sustainability development at the RCY. Moreover, the Environment Protection and Control Department (EPCD) at the RCY have contributed to the all of these pillars through policy and regulation to conserve past and future achievement. The sustainability concept at RCY became the first priority, which is involved in every project at the city. The RCY is responsible to implement the concept of sustainability from the start to the construction until operation [2]. According to the EPA Sustainability: "to create and maintain conditions, under which humans and nature can exist in productive harmony, that permit fulfilling the social, economic, and other requirements of present and future generations" [3]. The UN definition of sustainability 
development is "meets the needs of the present, while improving the ability of future generations to meet their own needs" [4]. RCY accommodates various views of global institutes and organizations such as EPA and UNDP into the Environment Regulation (RC-ER). However, national considerations for status of the basic support system are taken into account which gives clear vision on sustainability as well as indicator for Saudi Arabia. Brown et al, said that " $A$ clearer understanding of global sustainability and the development of appropriate indicators of the status of basic support systems would provide a useful framework for policy making"[5]. Moreover, indicators require a demonstration of value to the organization, Meadows said that "Indicators arise from values (we measure what we care about), and they create values (we care about what we measure)" [6].

\section{RCY Vision and mission toward sustainability development}

The Vision of the Royal Commission is to be the best choice for investors in petrochemical and energy-intensive industries and the leading contributor to the Kingdom's growth. The Mission of the Royal Commission is to: "sustainability in planning, promoting, developing and managing Petrochemical and Energy intensive industrial cities though successful customer focus and partnerships with investors, employees, communities and other stakeholders" $[7]$.

\subsection{RCY sustainability development objectives are:}

- Developing best-in-class industrial cities and attractive urban communities.

- $\quad$ Providing top quality, responsive services to the tenants and the community, at the most optimal cost.

- Ensuring availability of top education, healthcare, social and security services, and enforcing world-class environmental and safety.

- $\quad$ Ensuring availability of top city infrastructure and services.

- Achieving financial sustainability, and developing private sector participation.

- $\quad$ Attracting, developing and retaining qualified employees at all levels.

\subsection{Designing RCY with the concept of sustainability development}

Yanbu Industrial City is a modern manufacturing and residential community located on Saudi Arabia's Red Sea coast 350 kilometres. Built from scratch in less than two decades, two long pipelines were built to connect east and west coasts of Saudi Arabia, ensuring steady supplies of oil and gas in Yanbu to be transformed into refined products and feedstock for petrochemical industries, as an outgrowth of the country's drive toward industrial diversification. Yanbu is now the largest crude oil export terminal on the Red Sea and a leading manufacturing centre for petroleum products, petrochemicals, and consumer items. 16 major plants in (RCY) industrial park are helping satisfy local and world demand for refinery products, petrochemicals, and other commodities. Approximately 70 smaller manufacturing and 30 support industries are also in operation, while several more plants are being designed or constructed. Royal Commission capital is $\$ 221$ billion - the highest for any city in the country. Annual economic growth rate is $18 \%$ and investment growth is $5.8 \%$. 


\subsection{RCY Desirable, traditional and contemporary indicators}

The main goal of sustainability must be in general, flexibility, relevance and adaptability to the needs of countries according to capacities and priorities [8]. The result of other studies showed that the traditional sustainability focuses on $[9,10,11]$ : environmental development economic development social development.

Additionally, the RCY added more indicators to measure its performance with a comprehensive set of indicators that could tackle many aspects for improving the quality of life [8]. It originated between the strategic planning department and other pertinent department. Furthermore, the RCY in general emphasises on quality of living standards at all levels. Therefore, the following indicators serve the city according to the strategic vision for quality of life. The indicators are as follow: economy and finance, housing, education, energy, environmental best practise, strategic planning, health, telecommunication, urban planning, waste (water, solid), and sanitation.

\subsection{RCY Methodology for sustainability indicators}

Annually, The RC evaluates the sustainability indicators through three teams. The first team come from the concern departments which provide desired indicators which could help accomplished the objective against the goals. The next step is writing the report to the strategic and planning department. The second team is the RCY higher management consultant team for review and assessment. The third team is the external reviewer from the UN under a memorandum of agreement between the RCY and UNDP. The project titled "Evaluation of the Status of Sustainability in Madinat Yanbu Al-Sinaiyah (MYAS)" is part of the cooperation between Royal Commission of Yanbu and United Nations Development Program (UNDP) on sustainability. Additionally, the methodology provides a reliable and valid application of sustainability development. This process identifies the strengths and weaknesses of the indicators at each category. The sustainability report is produced every year for assessment by higher management and shares the best practice of sustainable development at the RCY.

\subsection{Sustainability indicators at the RCY}

The RCY is the Saudi vanguard for developing the petrochemical and refinery industry. Local and international experience added their contribution determining the best practices of sustainability development. RCY tested their sustainable development indicators through many judgements teams locally and internationally. Recently, RCY won many awards under the UN program of sustainability development such as UN LivCom award in 2013 as well as UNEP Sasakawa Prize. The RCY achieved recognition as the third city in the world for sustainable communities. Additionally, the RCY won the prize for first city in environment management "2014 Kingdom's International Award for Environmental Management". The following section demonstrates the detail of the twelve categories that shape and drive the sustainability development at the RCY, and it contains a comprehensive set of indicators. Internally, the comprehensive set of indicators designed as a questionnaire and answers dialogue that present the progress of the performance of the RCY. Moreover, the following categories are the outcome of the process of selecting sustainability indicators. Each category consists of a list of indicators to be reported in standardized format according to Sustainability Reporting Guidelines 
(SRG). The categories and the indicators as follow:

\subsubsection{Industrial and Economy growth}

Table 1 Industrial and Economy growth indicators

\begin{tabular}{|l|l|l|}
\hline $\begin{array}{l}\text { Number of industrial } \\
\text { rate }\end{array}$ & $\begin{array}{l}\text { Diversifying } \\
\text { investment }\end{array}$ & City unemployment rate \\
\hline Material supply & Innovation & Employee turnover Rate \\
\hline
\end{tabular}

\subsubsection{Financial support}

Table 2 Financial support indicators

\begin{tabular}{|l|l|}
\hline Own-source revenue & Income rate \\
\hline Financial stress & Tax rate \\
\hline
\end{tabular}

\subsubsection{Housing}

Table 3 Housing indicators

\begin{tabular}{|l|l|}
\hline Housing affordability & Housing waiting list \\
\hline Homeownership rate & Annual vacancy rate \\
\hline Company-owned housing & Privately-owned housing \\
\hline
\end{tabular}

\subsubsection{Education}

Table 4 Education indicators

\begin{tabular}{|c|c|c|c|}
\hline $\begin{array}{l}\text { Educational } \\
\text { attainment }\end{array}$ & $\begin{array}{l}\text { Primary } \\
\text { education }\end{array}$ & $\begin{array}{l}\text { students } \\
\text { completing } \\
\text { primary education }\end{array}$ & $\begin{array}{l}\text { Students completing } \\
\text { secondary education }\end{array}$ \\
\hline $\begin{array}{l}\text { Early } \\
\text { development }\end{array}$ & $\begin{array}{l}\text { Female school- } \\
\text { population }\end{array}$ & $\begin{array}{l}\text { Male school- } \\
\text { population }\end{array}$ & $\begin{array}{l}\text { Students completing } \\
\text { high education }\end{array}$ \\
\hline $\begin{array}{l}\text { Early } \\
\text { development }\end{array}$ & $\begin{array}{l}\text { Primary } \\
\text { education school }\end{array}$ & $\begin{array}{l}\text { Secondary } \\
\text { education school }\end{array}$ & $\begin{array}{l}\text { High } \\
\text { school }\end{array}$ \\
\hline $\begin{array}{l}\text { Number of higher } \\
\text { education }\end{array}$ & $\begin{array}{l}\text { Cultural } \\
\text { Diversity } \\
\text { education }\end{array}$ & $\begin{array}{l}\text { Knowledge } \\
\text { transfer }\end{array}$ & School Ranking \\
\hline
\end{tabular}

\subsubsection{Energy efficiency}

Table 5 Energy efficiency

\begin{tabular}{|l|l|}
\hline Energy supply & Energy efficiency policy \\
\hline Electrical energy use & Energy consumption of public \\
\hline Electrical interruptions & Renewable energy supply \\
\hline
\end{tabular}

\subsubsection{Environment best practise,}

Table 6 Environment best practice

\begin{tabular}{|l|l|l|l|}
\hline Air quality & Marine & $\begin{array}{l}\text { Disaster } \\
\text { preparedness and } \\
\text { response }\end{array}$ & Mangrove \\
\hline Water quality & $\begin{array}{l}\text { Greenhouse gas } \\
\text { emissions }\end{array}$ & $\begin{array}{l}\text { Monitoring } \\
\text { discharge }\end{array}$ & $\begin{array}{l}\text { Hazard waste } \\
\text { control }\end{array}$ \\
\hline $\begin{array}{l}\text { Lab machine and } \\
\text { dives availability }\end{array}$ & $\begin{array}{l}\text { Particulate matter } \\
\text { measurement }\end{array}$ & Study and research & Climate change \\
\hline
\end{tabular}




\begin{tabular}{|l|l|l|l|}
\hline $\begin{array}{l}\text { Renewable } \\
\text { Energy }\end{array}$ & Lab services & Awareness program & Inspection \\
\hline Penalty & $\begin{array}{l}\text { Sustainability } \\
\text { report }\end{array}$ & $\begin{array}{l}\text { Environment impact } \\
\text { assessment }\end{array}$ & $\begin{array}{l}\text { Industrial waste } \\
\text { Recycling }\end{array}$ \\
\hline
\end{tabular}

\subsubsection{Strategic planning}

Table 7 Strategic planning

\begin{tabular}{|l|l|}
\hline Customer Satisfaction & Short term actions \\
\hline Long term actions & Annual Business Plan \\
\hline Guidance system & Master plan \\
\hline Investment expenditure & Revenue generation \\
\hline
\end{tabular}

\subsubsection{Healthy and community life style}

Table 8 Healthy and community life style

\begin{tabular}{|l|l|}
\hline Numbers beds & Number of physicians \\
\hline Asthma hospitalization rate & Health care as percent of income \\
\hline Death from incidents & Death from disease \\
\hline Birth weight infants & Prenatal care \\
\hline Number of in-patient hospital & Number of nursing \\
\hline Population living in slums & Community engagement \\
\hline Household crime and & Cultural Diversity \\
\hline
\end{tabular}

\subsubsection{Telecommunication}

Table 9 Telecommunication

\begin{tabular}{|l|l|}
\hline Smart city project & Internet connections \\
\hline Cell phone connections & landline phone connections \\
\hline Equipment availability rate & \\
\hline
\end{tabular}

\subsubsection{Urban planning}

Table 10 Urban Planning

\begin{tabular}{|l|l|}
\hline Site Development plan & GIS \\
\hline Traffic planning & Geometric database availability \\
\hline Development control & Land survey \\
\hline
\end{tabular}

\subsubsection{Waste (water, solid) Sanitation}

Table 11 Waste (water, Solid) sanitation

\begin{tabular}{|c|c|c|c|}
\hline Water availability & $\begin{array}{l}\text { Water } \\
\text { consumption per } \\
\text { capita }\end{array}$ & $\begin{array}{ll}\text { Water } & \text { service } \\
\text { interruption } & \end{array}$ & $\begin{array}{l}\text { City waste } \\
\text { recycling rate }\end{array}$ \\
\hline $\begin{array}{l}\text { Waste disposed to } \\
\text { landfill }\end{array}$ & $\begin{array}{l}\text { Quantity } \\
\text { municipal } \\
\text { waste }\end{array}$ & $\begin{array}{l}\text { Quantity industrial } \\
\text { solid waste collection }\end{array}$ & $\begin{array}{l}\text { Wastewater } \\
\text { Treatment rate }\end{array}$ \\
\hline $\begin{array}{l}\text { Sea discharge } \\
\text { control }\end{array}$ & sanitary landfill & $\begin{array}{ll}\text { Hazardous } & \text { Waste } \\
\text { Generation } & \end{array}$ & $\begin{array}{l}\text { Landscaping and } \\
\text { irrigation rate }\end{array}$ \\
\hline
\end{tabular}


2.5.12 Transportation

Table 12 Transportation

\begin{tabular}{|l|l|l|}
\hline $\begin{array}{l}\text { Option of transport to } \\
\text { work }\end{array}$ & $\begin{array}{l}\text { Kilometres of high capacity } \\
\text { public transport system }\end{array}$ & Incident rate \\
\hline $\begin{array}{l}\text { Vehicle and passenger } \\
\text { kilometres travelled }\end{array}$ & Travel time to work & $\begin{array}{l}\text { Annual number of public } \\
\text { transport trips }\end{array}$ \\
\hline Transportation fatalities & Bicycle paths & Personal automobiles \\
\hline
\end{tabular}

\section{Conclusion}

The RCY structure is complicated and required an appropriate practice and methodology of sustainability development to figure suitable indicators. Moreover the indicators can be a powerful tool in addressing the status of the sustainability in the organization. RCY should manage and build their activities with the principles of sustainable development [6]; otherwise it will reinvent the wheel. Sustainability indicators must come from inside the organization not from outside. However, effective indicators should be easy to understand and reliable and can be trusted. The outcomes of the qualitative and quantitative data need a careful review, since it provides the organization with appropriate information and status on targeted and future goals. The indicators should provide a roadmap for higher management in achieving the Royal Commission's strategic objectives. Additionally, it can be used as tangible tools for assessing performance. The indicators can assist the organization by addressing action plans for future development, as well as areas which need organizational improvements.

\section{References}

[1] Charles J. Kibert L, Thiele Anna Peterson Martha Monroe The Ethics of Sustainability (2012).

[2] Royal Commission Environmental Regulation (RCER) Volume II, section A pp. 4- section W pp5, 2010.

[3] Federal Register. "Federal Leadership in Environmental, Energy, and Economic Performance" into the Agency's Green Purchasing Plan. Washington D.C October 8, 2009.

[4] World Commission on Environment and Development. "Our Common Future". Oxford: Oxford University Press ISBN 019282080X. pp. 27. (1987)

[5] Brown, Becky J., Mark E. Hanson, Diana M. Liverman, and Robert W. Merideth, J. "Global Sustainability: Toward Definition." Environmental Management 11 (6): pp 713-719. 1987

[6] Meadows, D. "Indicators and Information Systems for Sustainable Development", The Sustainability Institute, Hartland VT, USA1998.

[7] Royal commission "Annual business report (ABR) " \ page 12, 2015

[8] United Nations publication "Sustainable Development Challenges" Department of Economic and Social Affairs ISBN 978-92-1-109167-0 United Nations, New York, 2013

[9] Fiksel J , Eason T, Frederickson H” A Framework for Sustainability Indicators” at EP A pp 2012

[10] J. Keeble, S Topiol, S Berkeley "Using Indicators to Measure Sustainability Performance at a Corporate and Project Level”. Journal of Business Ethics May 2003, Volume 44, Issue 2-3, pp 149-158

[11] United Nations publication “Indicators of Sustainable Development: Guidelines and Methodologies” Third Edition Sales No. E.08.II.A.2 ISBN 978-92-1-104577-2 pp 29-40, October 2007 